\title{
EFFECT OF ORGANIC AMENDMENTS ON ZINC AVAILABILITY TO MAIZE - BENGAL GRAM CROPPING SEQUENCE IN A VERTISOL
}

\author{
C. Vijayakumar, ${ }^{1}$ G.V. Dasar ${ }^{2}$ and Basavarai; ${ }^{3}$
}

\begin{abstract}
Comparative efficacy of farmyard manure (FYM), vermicompost (VC), biogas slurry (BS) and poultry manure (PM) with and without $P$ enrichment on zinc availability to maize and bengal gram was evaluated in a vertisol under irrigated condition. On the basis of the uptake of zinc by maize and bengal gram, the performance of different organic amendments in maize followed the trend; $P M>B S=F Y M=V C$ and in bengol gram: $P M>B S>F Y M=V C$. Substantial buildup of available zinc in soil was observed due to the application of above amendments.
\end{abstract}

Wide spread deficiency of zinc in soil and crops have been reported in Vertisol. Some of the organic manures are rich in micronutrients, particularly in zinc. The present study was undertaken to study the effect of different organic amendments on the zinc availability to maize-bengal gram cropping sequence in a Vertisol of Karnataka.

1. Research Officer, Residue Laboratory, Rallis Research Centre, Bangalore.

2. Assistont Professor, College of Forestry, Sirsi.

3. Research Associate, Department of Soil Science and Agriculfural Chemistry, U.A.S., Dhanwad. 


\section{Material and Methods}

A field experiment was conducted at Main Research Station (MRS), University of Agricultural Sciences, Dharwad (Karnataka) on a Chromic Haplustert during kharif and rabi to investigate the direct and residual effect of phosphorus enriched organic manures to maize and bengal gram on the availability of zinc under irrigated condition.

The experiment was laid out in splif plot which consisted of three main plot treatments viz., Control $\left(0 \mathrm{~kg} \mathrm{P} \mathrm{O}_{5}\right.$ ha $\left.^{-1}\right), 50$ per cent of recommended dose of $\mathrm{P}(37.5 \mathrm{~kg}$ $\left.\mathrm{P}_{2} \mathrm{O}_{5} \mathrm{ha}^{-1}\right)$ and 100 per cent of recommended dose of $\mathrm{P}\left(75 \mathrm{~kg} \mathrm{P}_{2} \mathrm{O}_{5} \mathrm{ha}^{-1}\right)$ and nine sub-plot treatments viz., no organic manure, farmyard manure at $5+\mathrm{ha}^{-1}$, vermicompost af $2+h^{*}$, biogas slurry at 3 thal and poultry manure at 2 tha ${ }^{-1}$ P-enriched farmyard manure at $2.5 \mathrm{tha}^{-1}, \mathrm{P}$-enriched vermicompost at $1+h^{-3}$, P-enriched biogas slurry at $1.5+$ hal and P-enriched poultry manure at $1 \mathrm{tha^{-1 }}$. The total content of the phosphorus in all the selected farmyard manure $(F Y M)$, vermicompost $(V C)$, biogas slurry $(B S)$, poultry manure $(P M)$ were determined and the calculated quantities of each of organic manure was taken separately and mixed well with single superphosphate to the double the quantity of phosphorus in each organic manure. Single superphosphate mixed organic manure was filled separately in polyethylene bag and required quantity of water was added to each bag to maintain field condition (50\% of maximum water retention capacity of the manure). These bags were kept for a period of one month by adding water as per the requirement to maintain uniform moisture level in the entire incubated time. After the incubation period of 30 days, all these manures were dried and applied to soil. Maize variety (Deccan-103) and bengal gram (Annigeri-1) were grown as test crops. A basal dose of $75 \mathrm{~kg} \mathrm{~N}$ as urea, phosphorus as single superphosphate and $37.5 \mathrm{~kg} \mathrm{~K} \mathrm{O}$ as muriate of potash was applied. The characteristics of the soil were: $\mathrm{pH} \mathrm{7.2,} \mathrm{EC} 0.15 \mathrm{dSm}-1$, CEC $40.60 \mathrm{cmol}\left(\mathrm{p}^{+}\right) \mathrm{kg}^{-1}$; available P $13.2 \mathrm{~kg}$ $\mathrm{ha}^{-1}$ and available zinc $0.50 \mathrm{ppm}$ (below the critical level). Soil samples were collected at harvest stage of both the crops and available zinc was extracted with DTPA extractant and estimated by using Atomic Absorption Spectrophotomefer (AAS). Plant samples of maize and bengal gram were also collected at harvest stage and analysed for zinc by following standard procedure. The nutrient composition of organic manures is presented in Table 1.

Table-1: Nutrient composition of organic manures (on oven dry basis)

\begin{tabular}{|l|l|l|l|l|}
\hline Properties & FYM & VC & BS & PM \\
\hline $\mathrm{pH}(1: 2: 5)$ & 6.70 & 7.20 & 5.00 & 7.10 \\
Phosphorus $\left(\mathrm{P}_{2} \mathrm{O}_{5}\right) \%$ & 0.60 & 0.50 & 0.70 & 1.20 \\
Zinc (ppm) & 53.0 & 30.5 & 49.2 & 74.0 \\
\hline
\end{tabular}

Note $: F Y M=$ Farmyord manure; $V C=$ Vermicompost; $B S=$ Biogas slurry; $P M=$ Poultry manure. 


\section{Results and Discussion}

The highest zinc concentration of $44.83 \mathrm{ppm}$ was observed due to the addition of 100 per cent RDF-P. Among the organic manures and $P$-enriched organic manures the zinc concentration varied significantly from 41.00 to $53.33 \mathrm{ppm}$ over control $(29.50 \mathrm{ppm}$ ) (Table 2). The highest zinc concentration $53.33 \mathrm{ppm}$ was observed due to the addition of poultry manure. The zinc concentration in maize at harvest was higher in all organic manures treated plots. On the other hand its concentration reduced in $\mathrm{P}$ enriched manures treated plots due to high available phosphiorus would have reacted with available zinc and precipitated in soil, thus the concentration of zinc in plant reduced significantly. Among different organic manures both with and without P-enriched poultry manure treatments recorded higher zinc concentration in maize (straw + grain). The increase in concentration of zinc in maize might be due to high zinc content in poultry manure and high zinc release to crop.

Table-2: Effect of P-enriched organic manures at all levels of P-fertilizer on zinc concentration (ppm) in plant at harvest

\begin{tabular}{|c|c|c|c|c|c|c|c|c|}
\hline \multirow{2}{*}{\begin{tabular}{c} 
Treatment \\
\hdashline \\
\hdashline \\
0
\end{tabular}} & \multicolumn{4}{|c|}{$\begin{array}{c}\text { Maize } \\
\text { Pooled data for } 2 \text { years } \\
\text { (1997 and } 98)\end{array}$} & \multicolumn{4}{|c|}{$\begin{array}{l}\text { Bengal grom } \\
\text { Pooled data for } 2 \text { years } \\
\text { (1997.98 and } 1998.99 \text { ) }\end{array}$} \\
\hline & $M_{0}$ & $M_{1}$ & $\mathrm{M}_{2}$ & Mean & $\dot{M}_{0}$ & $M_{i}$ & $M_{2}$ & Mean \\
\hline$T_{1}$ - Control (RDF-NK) & 29.0 & 26.5 & 33.0 & 29.5 & 24.0 & 25.0 & 24.0 & 24.33 \\
\hline$T_{2}$-FYM@ @ $5 h^{-1}+$ RDF. NK & 43.0 & 37.5 & 42.5 & 41.00 & 31.0 & 35.5 & 30.5 & 32.33 \\
\hline $\mathrm{T}_{3} \cdot \mathrm{VC} @ 2 \mathrm{th \sigma ^{- }}+\mathrm{RDF} \cdot \mathrm{NK}$ & 39.0 & 42.0 & 44.5 & 41.83 & 35.0 & 35.5 & 33.5 & 34.67 \\
\hline$T_{4}=B S @ 3 t h a^{-1}+R D F-N K$ & 39.5 & 48.0 & 51.0 & 46.17 & 31.0 & 34.0 & 31.5 & 32.17 \\
\hline$T_{5} \cdot P M @ 2 t h a^{-1}+R D F=N K$ & 49.5 & 54.0 & 56.5 & 53.33 & 36.0 & 35.5 & 37.5 & 36.33 \\
\hline$T_{6}=$ P-FYM @ $2.5 t h h^{-1}+$ RDF.NK & 40.0 & 30.0 & 39.0 & 36.33 & 30.0 & 33.0 & 34.5 & 32.5 \\
\hline$T_{7} \cdot P . V C @ 1+h a^{\circ 1}+R D F+N K$ & 38.0 & 37.5 & 39.5 & 38.33 & 34.0 & 33.5 & 35.5 & 34.33 \\
\hline$T_{\mathrm{a}} \cdot P-B S @ 1.5 t h h^{-1}+$ RDF- NK & 32.5 & 41.0 & 45.0 & 39.50 & 36.0 & 35.0 & 35.0 & $35: 33$ \\
\hline$T_{9} \cdot P \cdot P M @ 1 t h a^{-1}+$ RDF. NK & 42.5 & 49.0 & 52.5 & 48.00 & 41.5 & 37.5 & 37.0 & 38.67 \\
\hline \multirow[t]{2}{*}{ Meon } & 39.22 & 40.61 & 44.83 & & 33.17 & 33.83 & 33.22 & \\
\hline & \multicolumn{2}{|c|}{ S.Emt } & \multicolumn{2}{|c|}{ C.D at $(5 \%)$} & \multicolumn{2}{|c|}{ S.Emะ } & \multicolumn{2}{|l|}{ C.D at $(5 \%)$} \\
\hline$M$ & \multicolumn{2}{|l|}{0.237} & \multicolumn{2}{|l|}{0.657} & \multicolumn{4}{|c|}{$0.104: 0.290$} \\
\hline $\mathrm{T} \quad \because, \cdots$ & & \multicolumn{2}{|l|}{1.686} & \multicolumn{2}{|c|}{0.217} & 0.603 & \\
\hline$M \times T(T$ at same level of $M)$ & \multicolumn{2}{|l|}{1.053} & \multicolumn{2}{|l|}{2.920} & \multicolumn{2}{|c|}{0.376} & 1.044 & \\
\hline $\begin{array}{l}M \times T \text { ( } M \text { at same or different } \\
\text { level of } T)\end{array}$ & 1.053 & & 4.367 & & 0.376 & & 1.562 & \\
\hline
\end{tabular}

RDF.NK $=$ Recommended dose of nitrogen and potash fertilizers, FYM $=$ Farmyard manure,

$\mathrm{VC}=$ Vermicompost, $\mathrm{BS}=$ Biogas slurn, $\mathrm{PM}=$ Pouttry manure

$M_{0}=$ No P-fertilizer, $M_{1}=50 \%$ recommended dose of P-fertilizer $\left(37.5 \mathrm{Kg} \mathrm{P}_{2} \mathrm{O}_{5}\right.$ ho.')

$\mathrm{M}_{2}=100 \%$ recommended dose of $\mathrm{P}$-fertilizer $\left(75.0 \mathrm{Kg} \mathrm{P}_{2} \mathrm{O}_{5} \mathrm{ha}^{\mathrm{l}}\right.$ )

The highest zinc concentration of $44.83 \mathrm{ppm}$ recorded due to application of 100 per cent RDF-P over control (39.22 ppm). Addition of fertilizer to soil, besides 
adding small quantity of micronutrients as contaiminats, it also increased the availability of native micronutrients in soil.

The interaction effect of $P$-enriched organic manures / organic manures with fertilizer $P$ at all levels of $P$-fertilizer had a significant effect on the zinc concentration in maize. This may be due to the difference in the available zinc status of the soil due to combined application of various organic manures and fertilizers.

The uptake of zinc in organic manures treated plots ranged from 0.65 to $0.85 \mathrm{~kg} \mathrm{ha}^{-1}$ in Penriched organic manures added plots from 0.59 to $0.92 \mathrm{~kg} \mathrm{ha}^{-1}$ over control $0.4 \mathrm{~kg} \mathrm{ha} \mathbf{a}^{-1}$ (Table 3). The highest uptake of zinc was recorded in P-enriched poultry manure $\left(0.92 \mathrm{~kg} \mathrm{ha}^{-1}\right)$. The uptake of zinc by maize from soil depends upon available zinc status of soil and biomass produced by the crop.

Table-3: Effect of Pmenriched organic manures at all levels of P-fertilizer on zinc uptake $\left(\mathrm{kg} \mathrm{ha}^{-1}\right)$ at harvest

\begin{tabular}{|c|c|c|c|c|c|c|c|c|}
\hline \multirow[t]{2}{*}{ Treatment } & \multicolumn{4}{|c|}{$\begin{array}{c}\text { Moize } \\
\text { Pooled data for } 2 \text { yeors } \\
\text { (1997 and } 98)\end{array}$} & \multicolumn{4}{|c|}{$\begin{array}{c}\text { Bengal gram } \\
\text { Pooled data for } 2 \text { years } \\
(1997.98 \text { and } 1998.99)\end{array}$} \\
\hline & $M_{0}$ & $M_{i}$ & $M_{2}$ & Mean & $M_{0}$ & $M_{2}$ & $M_{2}$ & Mean \\
\hline$T_{2} \cdot$ Control (RDF-NK) & 0.40 & 0.41 & 0.52 & 0.45 & 0.07 & 0.12 & 0.13 & 0.11 \\
\hline $\mathrm{T}_{2}=$ FYM @ 5t ho.1 + RDF-NK & 0.62 & 0.68 & 0.71 & 0.67 & 0.11 & 0.18 & 0.18 & 0.16 \\
\hline$T_{3} \cdot V C @ 2 t h o^{-1}+R D F \cdot N K$ & 0.55 & 0.66 & 0.72 & 0.65 & 0.11 & 0.17 & 0.19 & 0.16 \\
\hline $\mathrm{T}_{4}-\mathrm{BS} @ 3 \mathrm{~h} \mathrm{~h}^{-1}+\mathrm{RDF}-\mathrm{NK}$ & 0.56 & 0.77 & 0.84 & 0.72 & 0.11 & 0.17 & 0.19 & 0.16 \\
\hline $\mathrm{T}_{5}=\mathrm{PM} @ 2 t h a^{3}+\mathrm{RDF} \cdot \mathrm{NK}$ & 0.72 & 0.88 & 0.95 & 0.85 & 0.13 & 0.19 & 0.24 & 0.19 \\
\hline 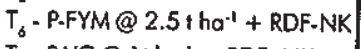 & 0.60 & 0.48 & 0.67 & 0.59 & 0.12 & 0.19 & 0.23 & 0.18 \\
\hline$T_{7} \cdot$ P.VC @ It ho' + RDF. NK & 0.56 & 0.60 & 0.64 & 0.60 & 0.13 & 0.18 & 0.23 & 0.18 \\
\hline$T_{g} \cdot P \cdot B S @ 1.5 t h a^{1}+$ RDF. NK & 0.48 & 0.66 & 0.76 & 0.64 & 0.14 & 0.20 & 0.23 & 0.19 \\
\hline 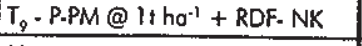 & 0.65 & 0.82 & 1.28 & 0.92 & 0.18 & 0.22 & 0.26 & 0.22 \\
\hline \multirow[t]{2}{*}{ Mean } & 0.57 & 0.67 & 0.79 & & 0.13 & 0.18 & 0.21 & \\
\hline & \multicolumn{4}{|l|}{ S.Emt } & \multicolumn{4}{|l|}{ S.Emะ } \\
\hline$M$ & \multicolumn{2}{|l|}{0.025} & \multicolumn{2}{|l|}{0.069} & \multicolumn{2}{|l|}{0.001} & \multicolumn{2}{|c|}{0.004} \\
\hline $\mathrm{T}$ & \multicolumn{2}{|l|}{0.042} & \multicolumn{2}{|l|}{0.118} & \multicolumn{2}{|l|}{0.002} & \multicolumn{2}{|l|}{0.007} \\
\hline$M \times T(T$ of some level of $M)$ & \multicolumn{2}{|l|}{0.073} & \multicolumn{2}{|l|}{0.205} & \multicolumn{2}{|l|}{0.004} & \multicolumn{2}{|l|}{0.001} \\
\hline $\begin{array}{l}\text { MxT ( } M \text { at some or different } \\
\text { level of } T \text { ) }\end{array}$ & \multicolumn{2}{|l|}{0.073} & \multicolumn{2}{|l|}{0.306} & \multicolumn{2}{|l|}{0.004} & \multicolumn{2}{|l|}{0.018} \\
\hline
\end{tabular}

RDF-NK = Recommended dose of nitrogen and potash fertilizers, FYM = Farmyard manure,

$\mathrm{VC}=$ Vermicompost, $\mathrm{BS}=$ Biogos slurry, $\mathrm{PM}=$ Poulity manure

$M_{0}=$ No P-fertilizer, $M_{1}=50 \%$ recommended dose of P-fertilizer $\left(37.5 \mathrm{Kg} \mathrm{P}_{2} \mathrm{O}_{5}\right.$ ha. $)$

$M_{2}=100 \%$ recommended dose of $P$-fertilizer $\left\{75.0 \mathrm{Kg} \mathrm{P}_{2} \mathrm{O}_{5} \mathrm{ha}^{-1}\right\}$

Addition of P-fertilizer at all levels increased significantly the uptake of zinc by maize and the highest zinc uptake $\left(0.79 \mathrm{~kg} \mathrm{ha}^{-1}\right)$ was observed due to application 
of 100 per cent RDF-P. Application of fertilizer to soil, besides adding small amount of micronutrients as an ingredient, it also improved the availability of zinc in soil. Thus increased the total biomass production of crops which ultimately resulted in higher uptake of zinc by crop. Anon (1986) observed higher uptake of Fe, Mn, Zn and Cu by maize due to application of NPK fertilizers over no-P-fertilizer.

Application of P-enriched poultry manure incombination with the addition of 100 per cent RDF-P was found to be superior in the uptake of zinc $\left(1.28 \mathrm{~kg} \mathrm{ha}^{-1}\right)$ by maize. Similar observations were reported by Anon. (1987) that incorporation of crop residues along with NPK fertilizers increased the uptake of $\mathrm{Fe}, \mathrm{Mn}, \mathrm{Zn}$ and Cu by maize and succeeding wheat crop in black soil.

The available zinc content in organic manures treated plots was ranged significantly from 0.79 to $1.83 \mathrm{ppm}$. In P-enriched organic manures added plots from 0.53 to $1.55 \mathrm{ppm}$ over control $(0.7 \mathrm{ppm})$ (Table 4). The highest availability of zinc in the soil was recorded in poultry manure treated plots (1.83 ppm). The available zinc

Table-4: Effect of P-enriched organic manures at all levels of P-fertilizer on zinc content (ppm) of soil at harvest

\begin{tabular}{|c|c|c|c|c|c|c|c|c|}
\hline \multirow[t]{2}{*}{ Treatment } & \multicolumn{4}{|c|}{$\begin{array}{c}\text { Maize } \\
\text { Pooled data for } 2 \text { years } \\
\text { (1997 and 98) }\end{array}$} & \multicolumn{4}{|c|}{$\begin{array}{c}\text { Bengal gram } \\
\text { Pooled data for } 2 \text { yeors } \\
(1997.98 \text { and } 1998.99)\end{array}$} \\
\hline & $M_{0}$ & $M_{1}$ & $M_{2}$ & Mean & $M_{0}$ & $M_{1}$ & $M_{2}$ & Mean \\
\hline $\mathrm{T}_{1} \cdot$ Control (RDF.NK) & 0.40 & 0.41 & 0.52 & 0.45 & 0.07 & 0.12 & 0.13 & 0.11 \\
\hline$T_{1} \cdot$ Control $(R D F-N K)$ & 0.28 & 0.27 & 0.26 & 0.27 & 0.31 & 0.30 & 0.21 & 0.30 \\
\hline$T_{2} \cdot F Y M @ 5 t h a^{-1}+R D F-N K$ & 1.63 & 1.62 & 1.61 & 1.62 & 1.71 & 1.70 & 1.69 & 1.70 \\
\hline $\mathrm{T}_{3}-\mathrm{VC} @ 2 \mathrm{tha^{ \prime l }}+\mathrm{RDF}-\mathrm{NK}$ & 0.80 & 0.79 & 0.78 & 0.79 & 0.92 & 0.91 & 0.90 & 0.91 \\
\hline$T_{4} \cdot 8 S @ 3 k h a^{-1}+$ RDF- NK & 1.52 & 1.51 & 1.50 & 1.51 & 1.57 & 1.56 & 1.55 & 1.56 \\
\hline$T_{5} \cdot P M @ 2 t h \sigma^{\cdot 1}+$ RDF. NK & 1.84 & 1.83 & 1.81 & 1.83 & 1.95 & 1.94 & 1.92 & 1.94 \\
\hline $\mathrm{T}_{6} \cdot$ P.FYM@2.5tha.l +RDF-NK & 1.25 & 1.24 & 1.23 & 1.24 & 1.34 & 1.33 & 1.32 & 1.33 \\
\hline$T_{7} \cdot$ P.VC @ itho.1 + RDF.NK & 0.54 & 0.53 & 0.52 & 0.53 & 0.61 & 0.60 & 0.59 & 0.60 \\
\hline $\mathrm{T}_{8}=\mathrm{P}-\mathrm{BS} @ 1.5 \mathrm{t} \mathrm{o}^{\cdot 1}+$ RDF. NK & 1.13 & 1.12 & 1.11 & 1.12 & 1.19 & 1.18 & 1.17 & 1.18 \\
\hline$T_{9}$-P.PM@ @ Itha.1 + RDF. NK & .1 .57 & 1.55 & 1.53 & 1.55 & 1.55 & 1.53 & 1.52 & 1.53 \\
\hline \multirow[t]{2}{*}{ Mean } & 1.18 & 1.16 & 1.15 & & 1.24 & 1.23 & 1.21 & \\
\hline & \multicolumn{2}{|l|}{ S.Em \pm} & \multicolumn{2}{|c|}{ C. D at $(5 \%)$} & \multicolumn{2}{|l|}{ S.Emt } & \multicolumn{2}{|c|}{ C.D ot $(5 \%)$} \\
\hline$M$ & \multicolumn{2}{|l|}{0.006} & \multicolumn{2}{|c|}{ NS } & \multicolumn{2}{|l|}{0.015} & \multicolumn{2}{|c|}{ NS } \\
\hline$T$ & \multicolumn{2}{|l|}{0.015} & \multicolumn{2}{|l|}{0.043} & \multicolumn{2}{|l|}{0.049} & \multicolumn{2}{|c|}{0.138} \\
\hline $\mathrm{MxT}$ (T at same level of $M)$ & \multicolumn{2}{|l|}{0.026} & \multicolumn{2}{|l|}{ NS } & \multicolumn{2}{|l|}{0.086} & \multicolumn{2}{|c|}{ NS } \\
\hline $\begin{array}{l}\text { MxT ( } M \text { ot some or different } \\
\text { level of } T \text { ) }\end{array}$ & \multicolumn{2}{|l|}{0.026} & \multicolumn{2}{|l|}{ NS } & 0.086 & & \multicolumn{2}{|c|}{ NS } \\
\hline
\end{tabular}

RDF. NK = Recommended dose of nitrogen and potash ferilizers, FYM = Formyard manure,

$\mathrm{VC}=$ Vermicompost, $\mathrm{BS}=$ Biogas slurry, $\mathrm{PM}=$ Poultry manure

$M_{0}=$ No P.fertilizer, $M_{1}=50 \%$ recommended dose of P-fertilizer $\left(37.5 \mathrm{Kg}_{2} \mathrm{O}_{5}\right.$ ho-1)

$M_{2}=100 \%$ recommended dose of $P$-fertilizer $\left\{75.0 \mathrm{Kg}_{2} \mathrm{O}_{5} \mathrm{hag}^{-1}\right\}$ 
in organic manures added plots was found more as compared to P-enriched organic manures. This may be due to high available $P$ content in $P$-enriched organic manures added plots might have precipitated zinc into unavailable zinc phosphate. Whereas, variation in available zinc in organic manures treated plots might be due to variation in zinc content of organic manures.

In organic manure and P-enriched organic manure treated plots the zinc concentration varied significantly from 32.33 to $38.67 \mathrm{ppm}$ over control 27.33 $\mathrm{ppm}$ (Table 4). The highest zinc concentration $38.67 \mathrm{ppm}$ noticed due to the addition of $P$-enriched poultry manure. The zinc concentration in organic manures was found higher as compared to $P$-enriched organic manures treated plots. This may be due to low available $\mathrm{P}$ content in organic manures than that of P-enriched organic manures. Whereas, difference in the concentration of zinc in organic manures treated plots might be due to variation in zinc content of organic manures used for the study.

The amount of zinc concentration was highest ( $33.83 \mathrm{ppm})$ at 50 per cent RDF-P and no P-fertilizer treated plot (33.17 ppm). The zinc concentration differed significantly with all levels of P-fertilizer. Application of fertilizers to soil, besides adding small quantity of zinc as impurities increased the availability of native zinc content of soil.

In the combined application of organic manures and P-levels, the highest zinc concentration $(41.50 \mathrm{ppm})$ was observed in the combination of no P-fertilizer and P-enriched pm at $1 \mathrm{tha} \mathrm{a}^{-1}$. This might be due to the increased available zinc status of the soil due to the addition of organic manures and P-fertilizer.

Among the P-enriched organic manure treated plots, residual poultry manure recorded maximum uptake of zinc $\left(0.22 \mathrm{~kg} \mathrm{ha} a^{\prime}\right)$ over no organic manure $(0.11 \mathrm{~kg}$ $\left.\mathrm{ha}^{-1}\right)$. The uptake of zinc by Bengalgram soil depends upon available zinc status in soil and biomass produced by the crop.

The amount of uptake of zinc was highest $\left(0.21 \mathrm{~kg} \mathrm{ha}^{-1}\right)$ at 100 per cent RDF-P as compared to no P-fertilizer $\left(0.13 \mathrm{~kg} \mathrm{ha}^{-1}\right)$. Residual effect of P-fertilizer in soil, improved the availability of native zinc in soil and thus increased the biomass production of crops which ultimately resulted in uptake of zinc by crops. Anon, (1986) noticed higher uptake of $\mathrm{Fe}, \mathrm{Mn}, \mathrm{Zn}$ and $\mathrm{Cu}$ by maize due to addition of NPK fertilizers over no P-fertilizer.

The interaction between $\mathrm{P}$-enriched organic manures and 100 per cent -KD-P showed significantly highest uptake of zinc $\left(0.26 \mathrm{~kg} \mathrm{ha}^{-1}\right)$ was observed in the combination of 50 per cent RD.P and P-enriched pm at $1+h^{-1}$. This may be 
ascribed to the more availability of zinc and the increase in yield due to interaction effect of organic manure and fertilizers which ultimately increased the uptake of zinc. The present observations were in accordance with the reports of Anon (1987).

The available zinc in organic manures applied plots $(0.91$ to $1.94 \mathrm{ppm})$ was found more as compared to $P$-enriched organic manures $(0.60$ to $1.53 \mathrm{ppm})$. This may be due to high available $\mathrm{P}$ content in $\mathrm{P}$-enriched organic manures which might have precipitated zinc into unavailable zinc phosphate. Whereas, variation in available zinc in organic manure treated plots might be due to variation in zinc content of organic manures used for the study.

In all, application of p-enriched poultry manure at $l+$ ha $^{-4}$ at all levels of $p$-fertilizer either individually or in combination significantly increased the uptake of zinc by both the crops. Substantial buildup of available zinc in soil was observed due to application of above treatment in both the direct and residual effect at kharif and rabi season, respectively.

\section{References}

Anonymous, 1986, Annual Report Advance Centre for Research on Black Cotton soils of Karnataka. U.A.S., Dharwad.

Anonymous, 1987, Annual Report Advance Centre for Research on Black Cotton soils of Karnataka, U.A.S., Dharwad. 